\title{
An evaluation toward the post-certification teacher performance in the natural history learning process for the elementary school degree
}

\author{
Siti Noor Azizah ${ }^{1}$ *, Suparwoto Suparwoto ${ }^{1}$, Zalik Nuryana ${ }^{2}$ \\ ${ }^{1}$ Universitas Negeri Yogyakarta. Jalan Colombo No. 1, Yogyakarta 55281, Indonesia \\ ${ }^{2}$ School of Education Science, Nanjing Normal University. 122 Ninghai Rd, Gulou, Nanjing, Jiangsu, China \\ * Corresponding Author. E-mail: ziahdr@yahoo.com
}

Received: 6 September 2018; Revised: 2 March 2020; Accepted: 24 April 2020

\begin{abstract}
The study aims at describing the teacher performance in the Natural History Learning Process for the Elementary School Degree throughout the Province of Yogyakarta Special Region from the four competencies namely personality competency, professionalism competency, pedagogy competence and social competency based on the self-assessment, the principal assessment, the peer assessment, the student assessment and the observation toward the learning process after the certification. The nature of the study is an evaluative study using the descriptive quantitative approach. The study itself was conducted in both the Public Elementary Schools and the Private Elementary Schools throughout the Province of Yogyakarta Special Regions. The subjects of the study were the teachers who had been teaching the Natural History in both schools who had passed the certification test in 2007 and 2008 and who had also been receiving the certification allowance. During the conduct of the study, the data gathering instruments that had been implemented were questionnaire, observation sheet and documentation. On the other hand, the data analysis technique that had been adopted was descriptive statistical analysis with percentage. Then, the results of the study show that the post-certification performance of Natural History teachers have been "Very Good" based on the personality, professionalism, pedagogy and social competency and also based on the results of the self-assessment, the principal assessment and the peer assessment. The details on the results of the post-certification teacher performance in this regard might be elaborated as follows: (1) personality competence $96.70 \%$; (2) professionalism competence $76.40 \%$; (3) pedagogy competence $83.30 \%$; and (4) social competence $88.90 \%$. Furthermore, the results of the student assessment assert that the post-certification of Natural History teachers belongs to the "Very Good" category with the assessment rate $96.70 \%$. Last but not the least, the results of the observation toward the teacher learning process also belong to the "Very Good" category with the following details: (1) pre-learning activities 93.30\%; (2) core activities 93.30\%; and (3) closing activities 73.30\%.
\end{abstract}

Keywords: evaluation, certification, teacher performance, natural history teachers for elementary school degree

How to Cite: Azizah, S., Suparwoto, S., \& Nuryana, Z. (2020). An evaluation toward the postcertification teacher performance in the natural history learning process for the elementary school degree. Psychology, Evaluation, and Technology in Educational Research, 2(2), 115128. doi:http://dx.doi.org/10.33292/petier.v2i2.16

\section{INTRODUCTION}

The national education in the domain of education deals with the efforts of brightening the life of the nation. The efforts themselves have been specified to the improvement of the Indonesian human resources who have faith, piety and nobility and who also master the science, the technology and the art in order to achieve the advanced, fair, prosperous and civilized society based on Pancasila and 1945 Consitution. The efforts of improving the human resources quality, especially the quality of the Natural History teachers for the Elementary School Degree, have been pursued since the implementation of the 1975 Curriculum, the 1984 Curriculum, the 1994 Curriculum, the 2004 Curriculum and eventually the 2006 Curriculum (the Educational Unit Level Curriculum or also known as KTSP, 
which stands for Kurikulum Tingkat Satuan Pendidikan). Since 1975, the development of the curriculum that has orientations toward objectives and that complements the representative Natural History facilities, the Natural History textbooks and the Natural History teacher workshops has been pursued. After the 1975 Curriculum had been implemented for 10 years, in 1984 a new curriculum was developed under the label "Process-Skills Approach" or also known as PKP (which stands for Pendekatan Keterampilan Proses). Then, in 1994, a supplement was developed in order to complete the ProcessSkills Approach in order to improve the previous curriculum. Eventually, in 2004 another curriculum was issued under the label "Competence-Based Curriculum" or also known as KBK (which stands for Kurikulum Berbasis Kompetensi). After two years of implementation, the teacher professionalism started to be developed through the implementation of the Educational Unit-Level Curriculum.

The efforts of improving the human resources quality, especially for the Natural History teachers in the Elementary School Degree, have been one of the fundamental capital in the domain of education. Therefore, the learning process of Natural History in the Elementary School Degree is expected to lead the attitudes and the behaviours of the human resources toward the better direction. In this regard, teachers are one of the elements in the educational process because the teachers serve as instructors, trainers and also educators. (Djohar, 2007, p. 11; Nisa, 2015) argues that the profile of a teacher should consist of three fundamental elements namely: (1) the competencies in teaching the given subjects; (2) the professionalism in carrying the teaching duties; and (3) the skillfulness in carrying out the daily duties. In relation to the argument, (Alsrhid, 2012, p. 18) states that the mastery of science, the professional competence, the emotional competence and the personal competence of a teacher plays a very vital role within the effectiveness and the efficiency of an educational process. A professional teacher is required to have the Strata-1 (S-1) or the Diploma-IV (D-IV) as the minimum educational background, to master the four competencies (pedagogic, professional, social and personal competencies), to attain educator certification, to display physical and spiritual health and to have the capacity of manifesting the national education objectives.

The Minister of National Education Regulation Number 18 of 2007 on In-Service Teacher Certification marks the beginning of the teacher certification program implementation throughout Indonesia. Certification program is a program that has been initiated by the government with more directions toward the efforts of improving the learning process results by assigning the competent teaching staffs in accordance to their domain. The term competent in this regard implies that within the conduct of the duty and the responsibility a teacher should be professional.

Within the context of teacher certification, although portfolio is part of physical evidence (document) that describes the experiences or the outstanding achievement during the professional conduct of teaching duty in certain intervals, the most important point is that the spirit to perform the teaching duty in maximum manner should be preserved after the certification has been completed. Therefore, the factor of truth behind the portfolio lies in the hands of each teacher. On the one hand, the implementation of certification by means of portfolio speeds up the certification process. Unfortunately, on the other hand, such certification process implies certain weaknesses. However, the main attention should be attaining the best solution by benefitting the existing potentials for pursuing maximum performance instead of blaming the existing procedures.

The evaluation process toward the teacher performance assists the educational institution to achieve a number of objectives. This includes the advancement or the delay in the performance results in accordance to the objective criteria and the consideration toward the balance among the professional requirements, the qualification, the pyschological characteristics, the cognitive characteristics, the social characteristics and the strong and weak performance of a teacher. Therefore, through the evaluation an educational institution might take necessary steps in order to ensure that the level of teacher performance development is always improved (Alsrhid, 2012, pp. 18-19).

Performance is a combination of three factors, which consist of: (1) knowledge, especially in relation to the work responsibility; (2) experience, in relation to the terms of service and the substance of the work responsibility (the longer the terms of service is, the more skillful a teacher will be and the more possible the teacher will be in improving his or her skills and capacities); and (3) personality, in the form of internal conditions with regards to the domain of his or her occupation such as talent, interest, cooperative capacity, persistence, honesty, attitude and work motivation. The Directory of Teaching Staffs, The General Directory of Teachers and Teaching Staffs Quality Improvement, Department of National Education (2009, pp.39-41) has prepared the Teacher Capacity Assessment 
Instrument (APKG, which stands for Alat Penilaian Kemampuan Guru) in order to assess the teacher performance in performing the learning activities within the classroom. The Instrument consists of the assessment toward the teacher performance in planning the learning process and the assessment toward the teacher performance in conducting the learning process.

The great figure of the teachers who have been certified seems to be unable to secure the improvement of the educational quality in the school degree and even in the national degree. For example, in the Regency of Kulon Progo, the Province of Yogyakarta Special Region, the educational situation has been concerning. The number of Elementary School/Madrasah Ibtidaiyah Degree teachers in 2004 has been 3,151 people, consisting of 2,671 capable teachers and 480 incapable teachers. On the other hand, in relation to the teacher competence, the breakthrough that the Regent of Sleman, Drs. Ibnu Subiyanto, Akt., has done is connecting the teacher competence to the teacher welfare and the teacher achievement. The Regent of Sleman at this time has considered that many teachers in the Regency of Sleman have been incapable for teaching due to the poor teacher recruitment system in the past. Therefore, he has made a decision by awarding the teachers with achievement while eliminating the teachers without achievements (Sariwulan et al., 2019; Sasmoko et al., 2018; Suparlan, 2008).

Departing from the overall elaboration, the problem that will be discussed in the study is the evaluation toward post-certification Natural History teacher performance in the Elementary School Degree throughout the Province of Yogyakarta Special Region. Thus, the objective of the study is to describe the post-certification Natural History teacher performance in the Elementary School Degree based on four competencies namely: (1) personality competence; (2) professionalism competence; (3) pedagogy competence; and (4) social competence. Then, the assessment on the four competencies will be based on: (1) the teacher self-assessment; (2) the principal assessment; and (3) the peer assessment. Furthermore, the description on the post-certification Natural History teacher performance in the Elementary School Degree throughout the Province of Yogyakarta Special Region will be based on the student assessment and the information on the teacher performance which includes: (1) lesson plan and implementation; and (2) learning results assessment implemented by the teachers.

\section{METHOD}

The nature of the study was an evaluative research using the descriptive quantitative approach. The study was conducted in both the Public and the Private Elementary Schools throughout the Province of Yogyakarta Special Region covering one city and four regencies namely: (1) the Regency of Bantul; (2) the Regency of Gunung Kidul; (3) the Regency of Kulon Progo; (4) the Regency of Sleman; and (5) the City of Yogyakarta. The conduct of the study took place for nine months starting from August 2010 until April 2011.

Within the conduct of the study, the subjects consisted of male of female teachers who had been teaching Natural History in the Elementary School Degree. In order to limit the population, three criteria were assigned namely: (1) the teachers had passed the certification process by means of portfolio access; (2) the certification should be between 2007 and 2008; and (3) the teachers had retrieved the certification allowance. As a result, the samples in the study consisted of 30 Natural History teachers for Elementary School Degree who had passed the certification program between 2007 and 2008 by means of portfolio access and had retrieved the certification allowance.

The data gathering technique that had been implemented were questionnaire, observation sheet and documentation. The teacher performance questionnaire contained a list of questions, statements, and short responses intended to gather the data on the performance of the Natural History teachers. The questionnaire was distributed to the sampled teachers (self-assessment), the principals/superiors, the peers and the students from the schools where the teachers had been working. This instrument was adopted from the Teacher Capacity Assessment Instrument that had been designed by the Directory of Teaching Staffs, the General Directory of Teachers and Teaching Staffs Quality Improvement, the Department of National Education (2009, pp.39-41). The Teacher Capacity Assessment Instrument had been assigned in order to gather the data on the teacher performance from the perspective of the personality competence, the professionalism competence, the pedagogy competence and the social competence. 


\section{Psychology, Evaluation, and Technology in Educational Research, 2 (2), 2019, 118}

Siti Noor Azizah, Suparwoto Suparwoto, Zalik Nuryana

On the other hand, the observation sheet was completed by the researcher during the observation toward the learning process that the teachers had conducted within the classroom. The documents that supported the observation process were the Lesson Plans and the other learning instruments.

Last but not the least, the data analysis technique that had been implemented in the study was the descriptive statistics. Through the implementation of the descriptive statistics, the description on the symptoms within the study and the answers toward the problem within the study might be attained. Then, since the data analysis type that had been attained was the descriptive data, the data were presented in the form of graphics, mean ideal (MI), standard deviation ideal (SDI), the highest ideal score, and the lowest ideal score for each sub-variable as the criteria in the study.

\section{RESULTS AND DISCUSSIONS}

The characteristics of the respondents within the study cover their conditions within the last three years. Then, in order to be selected as the respondents for the study, the respondents should be the Natural History teachers for the Elementary School Degree who have passed the certification program between 2007 and 2008 through the portfolio access and who have also retrieved the certification allowance. In total, there are 30 Natural History teachers for the Elementary School Degree from both the Public and the Private Elementary Schools. The details on the number of the teachers might be elaborated as follows: (1) 3 teachers were selected from 3 Elementary Schools in the Regency of Sleman; (2) 3 teachers were selected from 3 Elementary Schools in the City of Yogyakarta; (3) 4 teachers were selected from 3 Elementary Schools in the Regency of Gunung Kidul; (4) 9 teachers were selected from the Regency of Kulon Progo; and (5) 11 teachers were selected from 6 Elementary Schools in the Regency of Bantul. In a further detail, the characteristics of the respondents might be described as follows: (1) $76.70 \%$ respondents were graduated from Strata-1 Study Program while $23.30 \%$ respondents were earning their degree from Strata-1 Study Program; (2) $63.30 \%$ respondents had attended training/education program for more than three times; (3) $26.70 \%$ respondents used to join scientific writing contest/competition; (4) $26.70 \%$ had been the teacher practice advisors; (5) $70.00 \%$ respodents had been the advisors the students' competitive events; (6) $13.30 \%$ respondents used to compose learning module; (7) $13.30 \%$ respondents used to compose learning dictate; (8) 3.30\% respondents used to compose textbooks for their own use; (9) $20.00 \%$ respondents used to compose other learning materials; (10) $56.70 \%$ respondents used to conduct a study; (11) $33.30 \%$ respondents used to be reviewers or test-item compilers; (12) 56.70\% respondents used to design learning media for their students; (13) $33.30 \%$ respondents used to design effective and efficient technology; (14) $83.30 \%$ respondents used to attend scientific forum; (15) 40.00\% respondents used to attend/to be active in educational organizations; (16) $90.00 \%$ respondents were active in social organizations; (17) $93.30 \%$ respondents used to be assigned in extra duty; (12) $43.30 \%$ respondents used to receive educational award; (18) $33.30 \%$ respondents used to be assigned in special duty; and (19) $83.30 \%$ respondents met the 24 hour-workload in one school.

As having been implied by the title, the term evaluation refers to assessment. In a wide definition, evaluation refers to the process of planning, attaining and supplying highly necessary information in order to make decisions. Similarly, Tyler (Arikunto, 2016; Widiastini et al., 2018) states that evaluation refers to the process of gathering data in order to define how far in which case and in which part the educational objectives have been achieved. Then, generally the objective of evaluation refers to the efforts of gathering, managing and presenting data as the input for the decision-making activities. According to Fernandes $(1984$, p.1), evaluation is the systematic of the worth and merit of some object. Thus, in this regard systematic investigation is a set of planned activities that are performed continuously at the beginning, in the middle, and at the end of a program. Furthermore, Weiss (1997) states that the purpose of evaluation research is to measure the effect of a program against the goals it set to accomplish as a means of contributing to subsequent decision-making about the program and improving future program. Furthermore, the general function of evaluation is to identify the level of success and failure of a program and also to provide feedback for overcoming the existing problems. As an action or a process, evaluation at least has three main functions namely: (1) to measure progress; (2) to support planning; and (3) to improve or refine (Jalinus \& Nabawi, 2017; Sudijono, 2012, p. 8). As having been explained by (Gronlund, 1985, p. 6; Grounlund et al., 1990), evaluation is a much more comprehensive and inclusive termm than measurement; on the other hand, evaluation always 
Psychology, Evaluation, and Technology in Educational Research, 2 (2), 2019, 119

Siti Noor Azizah, Suparwoto Suparwoto, Zalik Nuryana

includes value judgments concerning the desirability of the result. Another function of evaluation is to observe the achievement of the program targets in order to determine how sufficient a program has been implemented. Therefore, the benchmark within evaluation is the objectives that have been formulated within the stage of the program implementation. In relation to the stakeholders, the results of program evaluation might be used in the domain of administrative responsibility for the stakeholders or the publication effort.

Law of Teachers and Lecturers No. 14 of 2005 explains that certification is a process of distributing certificates to both the teachers and the lecturers. Educator certificate is a formal evidence as part of acknowledgement for both the teachers and the students as professionals. Teacher certification thus aims at determining the teacher proficiency in conducting their duty as the agent of learning and also at achieving the national education objectives, improving educational process and quality, improving teacher dignity and improving teacher professionalism. These statements describe that the provision of certification enables the presence of optimization efforts toward the teacher performance in every single educational unit throughout Indonesia. Therefore, it is expected that teacher certification might impact the improvement of the teacher quality through the learning process that has been developed in the school. In addition to the objectives that have been stated, certification program also provides several benefits as follows: (1) protecting the teacher profession from the incompetent practices that might deteriorate the teacher impression; (2) protecting the society from the ill-qualified and unprofessional educational practices; and (3) improving the teacher prosperity since certification incurs certain financial benefits especially for the certificate holders (Mardapi \& Herawan, 2019; Nabila, 2016; Payong, 2011). In a specific manner, the in-service teacher certification is intended for the teachers, both the civil-servant ones and the non-civil-servant ones, who have been serving for quite a long time (Payong, 2011). The in-service teachers refer to both the civil-servant teachers and the non-civil-servant teachers who have been teaching in the government-run, the regional government-run and the society-run educational units under certain contracts or work agreements. The teachers who have passed the teacher certification test and met the other requirements in accordance to the given criteria will be provided with the professional allowance which amount is one-time slary as the effort by the government in improving the teacher prosperity. By improving the teacher quality and prosperity, it is expected that the Indonesian learning and educational quality might be improved.

According to Suyanto dan Abbas (2001), regardless of the learning technique, method, and approach that will be implemented in the teaching-learning process within the classroom, all of these aspects might not be separated from the role of the teachers (Natuna \& Rinaldi, 2017). The teachinglearning process shall not take place without the presence of a teacher. The teacher is positioned as the center of learning process implementation within the school. Therefore, the teacher will be the discussion topic and the highlight of many parties in relation to their performance. In other words, the teacher has a very strategic role as educator, manager, administrator, supervisor, leader, innovator, motivation, dynamist, evaluator and facilitator (Sariwulan et al., 2019; Suparlan, 2008).

Furthermore, Munir (2008, p. 31) states that performance refers to the work results based on the assessment toward the duty and the function of certain officials by certain institutions. On the contrary, Fattah (1999, p. 19) states that work, performance achievement, or performance might be defined as an expression of capability that has been based on the knowledge, the attitude, the skills and the motivation in generating something. From the perspective of work management, Stiffler, as having been quoted by Damanik (2012), states that teacher performance might be categorized into organizational performance and individual performance. The organizational performance derives from the aspects of organizational management, which pays attention to the customers (customer focus), the leadership, the system approach to management and the continual improvement. In this regard, the role of the school principal, the colleagues, and their fellow school members derives from the teacher performance assessment. On the other hand, the individual performance derives from the parts of the teacher reinforcement in internalizing the strong commitment so that the teachers will be independent and will be aware that the professional duty is a calling to their soul. As a result, these aspects will trigger the self-motivation, internalize the persistence, improve the self-capability. Therefore, if the job of a teacher is considered as a profession, then the implication of the job will involve responsibility, skills and collegiality. Then, the responsibilities of a teacher are namely: (1) teaching duty; (2) exercise; (3) guidance; and (4) role model. As a role model, a teacher should afford how to give a good teaching, how to improve the students' achievements, and how to shape the students in order to be 
advanced by maintaining a balanced, harmonious and linear relationship. The skills of a teacher in relation to his or her profession are related to the willingness to be committed to the lifelong learning process and also to the willingness to update his or her knowledge and its development. On the other hand, collegiality deals with the relationship between the teacher and his or her professional organization which develops the relationship among the fellow teachers and the relationship between the teachers and the other parties in order to solve the problems of both the nation and the state.

Hastuti (2005) in her study has reported the performance of the Natural History teachers for the Elementary School Degree in the Province of Yogyakarta Special Region based on the self-assessment results from the perspective of four competencies namely personality competence, pedagogy competence, professionalism competence, and social competence. In relation to the report, with the maximum score 100 hundred the results of the description of the teacher performance based on the selfassessment results from the perspective of the four competencies within the study might be consulted in Table 1.

Table 1. The Distribution on the Categorization for Each Competence of Teacher Performance Based on the Self-Assessment Results

\begin{tabular}{cccc}
\hline Competence & Interval & $\%$ & Category \\
\hline Personality & $X \geq 36$ & 96.70 & Very Good \\
Professionalism & $X \geq 64$ & 83.30 & Very Good \\
Pedagogy & $X \geq 52$ & 93.30 & Very Good \\
Social & $X \geq 28$ & 96.70 & Very Good \\
\hline
\end{tabular}

Departing from the results in Table 1, it is found that most of the teachers' personality competence has fallen into the "Very Good" category (96.70\%) while the remaining 3.30\% has fallen into the "Good" category. Then, most of the teachers' professionalism competence has fallen into the "Very Good" category (83.30\%) while the remaining $16.70 \%$ has fallen into the "Good" category. Next, most of the teachers' pedagogy competence has fallen into the "Very Good" category $(93.30 \%)$ while the remaining $6.70 \%$ has fallen into the "Good" category. Last but not the least, most of the teachers' social competence has fallen into the "Very Good" category $(96.70 \%)$ while the remaining $3.30 \%$ has fallen into the "Good" category.

Next, based on the school principal assessment, the performance of Natural History teachers for the Elementary School Degree is also viewed from the perspective of the four competencies namely the personality competence, the professionalism competence, the pedagogy competence and the social competence. With the maximum score 100, the results of the description toward the four competencies within the teacher performance based on the school principal assessment might be consulted in Table 2.

Table 2. The Distribution on the Categorization of Each Competence within the Teacher Performance Based on the School Principal Assessment

\begin{tabular}{cccc}
\hline Competence & Interval & $\%$ & Category \\
\hline Personality & $\mathrm{X} \geq 48$ & 96.70 & Very Good \\
Professionalism & $\mathrm{X} \geq 60$ & 70.00 & Very Good \\
Pedagogy & $\mathrm{X} \geq 88$ & 76.70 & Very Good \\
Social & $\mathrm{X} \geq 48$ & 86.70 & Very Good \\
\hline
\end{tabular}

Departing from the results in Table 2, it is found that most of the teachers' personality competence has fallen into the "Very Good" category $(96.70 \%)$ while the remaining $3.30 \%$ has fallen into the "Good" category. Then, most of the teachers' professionalism competence has fallen into the "Very Good" category (70.00\%) while the remaining 30.00\% has fallen into the "Good" category. Next, most of the teachers' pedagogy competence has fallen into the "Very Good" category $(76.70 \%)$ while the remaining $23.30 \%$ has fallen into the "Good" category. Last but not the least, most of the teachers' social competence has fallen into the "Very Good" category $(86.70 \%)$ while the remaining $13.30 \%$ has fallen into the "Good" category.

Next, based on the peer assessment, the performance of Natural History teachers for the Elementary School Degree is viewed from the perspective of the four competencies as well namely the personality competence, the pedagogy competence, the professionalism competence and the social competence. With the maximum score 100, the results of the description toward the four competencies 
within the teacher performance based on the school principal assessment might be consulted in Table 3.

Table 3. The Distribution on the Categorization of Each Competence within the Teacher Performance Based on the School Principal Assessment

\begin{tabular}{cccc}
\hline Competence & Interval & $\%$ & Category \\
\hline Personality & $\mathrm{X} \geq 48$ & 96.70 & Very Good \\
Professionalism & $\mathrm{X} \geq 60$ & 70.00 & Very Good \\
Pedagogy & $\mathrm{X} \geq 88$ & 86.70 & Very Good \\
Social & $\mathrm{X} \geq 48$ & 83.30 & Very Good \\
\hline
\end{tabular}

Departing from the results in Table 3, it is found that most of the teachers' personality competence has fallen into the "Very Good" category (96.70\%) while the remaining 3.30\% has fallen into the "Good" category. Then, most of the teachers' professionalism competence has fallen into the "Very Good" category (70.00\%) while the remaining 30.00\% has fallen into the "Good" category. Next, most of the teachers' pedagogy competence has fallen into the "Very Good" category $(86.70 \%)$ while the remaining $13.30 \%$ has fallen into the "Good" category. Last but not the least, most of the teachers' social competence has fallen into the "Very Good" category $(83.30 \%)$ while the remaining $16.70 \%$ has fallen into the "Good" category.

Furthermore, the teacher performance is also assessed by means of student questionnaire. The student questionnaire consists of 31 question items through which the students should assess the performance from each of their teacher and the number of the respondents within this assessment is 5 students. The mean score from the results of the questionnaire that has been distributed to the 5 students is calculated and thus the mean score will be the final score of the teacher performance assessment by the students. The description on the student assessment toward the teacher performance might be consulted in Table 4 .

Table 4. The Distribution on the Categorization of Teacher Performance Based on the Student Assessment

\begin{tabular}{cccc}
\hline Interval & Frequency & $\%$ & Category \\
\hline $\mathrm{X} \geq 13$ & 29 & 96.70 & Very Good \\
$10 \leq \mathrm{X}<13$ & 1 & 3.30 & Good \\
\hline
\end{tabular}

Similar to the results of the self-assessment, the school principal assessment and the peer assessment, the results of the student assessment show that most of the teacher performance has fallen into the "Very Good" category $(96.70 \%)$ while the remaining $3.30 \%$ has fallen into the "Good" category. Therefore, it might be concluded that the performance of the Natural History teachers in the Province of Yogyakarta Special Region has fallen into the "Very Good" category.

In order to view the tendency level within the teacher performance in each aspect, the data that have been attained should be categorized further. Departing from the observation, the results of the categorization for each aspect of teacher performance might be consulted in Table 5.

Table 5. The Distribution on the Categorization of Each Aspect within the Teacher Performance Based on the Observation Results

\begin{tabular}{cccc}
\hline Competence & Interval & $\%$ & Category \\
\hline Pre-Learning & $\mathrm{X} \geq 8$ & 93.30 & Very Good \\
Core Activities & $\mathrm{X} \geq 80$ & 93.30 & Very Good \\
Conclusion & $\mathrm{X} \geq 8$ & 73.30 & Very Good \\
\hline
\end{tabular}

Departing from the results in Table 5, it is found that within the pre-learning stage most of the teacher performance has fallen into the "Very Good" category $(93.30 \%)$ while the remaining $6.70 \%$ has fallen into the "Good" category. Then, within the core activity stage most of the teacher performance has fallen into the "Very Good" category (93.30\%) while the remaining 6.70\% has fallen into the "Good" category. Next, within the concluding stage most of the teacher performance has fallen into the "Very Good" category $(73.30 \%)$ while the remaining $26.70 \%$ has fallen into the "Good" category. Therefore, it might be implied that the post-certification Natural History teacher performance for the Elementary School Degree throughout the Province of Yogyakarta Special Region has fallen into the "Very Good" category based on the observation results. 
Mulyasa (2007, p. 77) states that operationally the capacity to manage the learning process entails three managerial functions namely planning, implementation and control. Several activities of the teacher performance that has been conducted within the lesson plan include: (1) formulating the learning objectives; (2) determining the learning materials/the lesson materials; (3) implementing the learning strategy and method; (4) selecting the appropriate learning media; and (5) performing learning evaluation.

In formulating the lesson plans, there are several clues that might be benefitted namely: (1) referring to the competence standards; and (2) assessing the relevance to the indicators that have been assigned. Indicators refer to the measurable behaviours that consist of knowledge, attitudes and skills. Indicators are assigned as the marks of the successful learning objectives achievement, which certainly describes the competence achievement. Therefore, the domain of the learning objectives should be comprehensive, meaning that all aspects in the competence domain (the cognitive, affective, and psychomotor domain), the objectives that the school would like to meet and the relevance to the governing curriculum have been accounted.

In this regard also, learning materials refer to all set of learning materials that have been systematically designed in order to assist the teachers in conducting the learning activities and to enable the students learn. The learning/lesson materials might be determined by paying attention to the following principles: (1) the learning/lesson materials should be designed in accordance to the learning objectives that have been formulated based on the governing curriculum; and (2) the learning/lesson materials that contain enrichment should be provided.

Last but not the least, the selection and the implementation of the learning strategy/method should be adjusted to the learning objectives that have been formulated and to the learning materials as well. The implementation of the learning method should be based on the students' capacity by devising the learning process steps that have been based on the method that has been implemented. In the same time, the time allocation for the learning process should be in accordance to proportion and this also applies to the time allocation for the enrichment materials.

Within the learning process of Natural History, learning media is very vital. There are many media that might be benefitted within the learning process and these media span from the most modest one to the most modern one. In relation to the statement, one of the aspects within the teacher performance in the lesson plan is the selection on the appropriate learning media for implementation during the learning process. The reason is that the term implementation in this regard refers to the process of ensuring that the teaching-learning process has had the necessary human resources and facilities so that the competence and the achievement of the desired learning objectives might be enabled. Therefore, the selection of the learning media should be adjusted to the learning objectives and materials, the classroom conditions, the evaluation types, the teacher capacities and the students' needs and development.

As having been implied previously, the third function is control. The term control might also be regarded as evaluation or assessment. Control has been an important component that should be afforded by the teachers at the end of the learning process. The objective of evaluation is to ensure that the performance achievement has been in accordance to the plan that has been devised or the objective that has been formulated. Consequently, control, or assessment, refers to a set of activities for attaining, analysing and interpreting the data on the learning process and results of the students systematically and continuously so that the data will be meaningful information within the decision-making process. Therefore, the composition of evaluation should refer to the learning objectives, the evaluation types (test or non-test), the evaluation forms (namely oral or written), the performance observation, the attitude, the artwork assessment (project or product), the portfolio use and the self-assessment. In the same time, the evaluation should be adjusted to the available time allocation and the evaluation principles.

Most of the respondents, in this case the teachers, have implemented the Contextual Teaching and Learning (CTL) Method in the learning process, the role play, the observation and the simple experiment through the guidance of the teachers in the classroom. The students attend to the learning process by having small-group discussions in order to solve the problems that the teachers have proposed. Then, the teachers guide the students to be able to communicate the arguments from their small groups; afterward, the students are invited to draw the conclusions at the end of the learning process altogether in the same time. This sequence has made the learning process meaningful, 
enjoyable and refreshing for the students. A clear comparison on the categorization for each competence based on the self-assessment might be consulted in Figure 1.

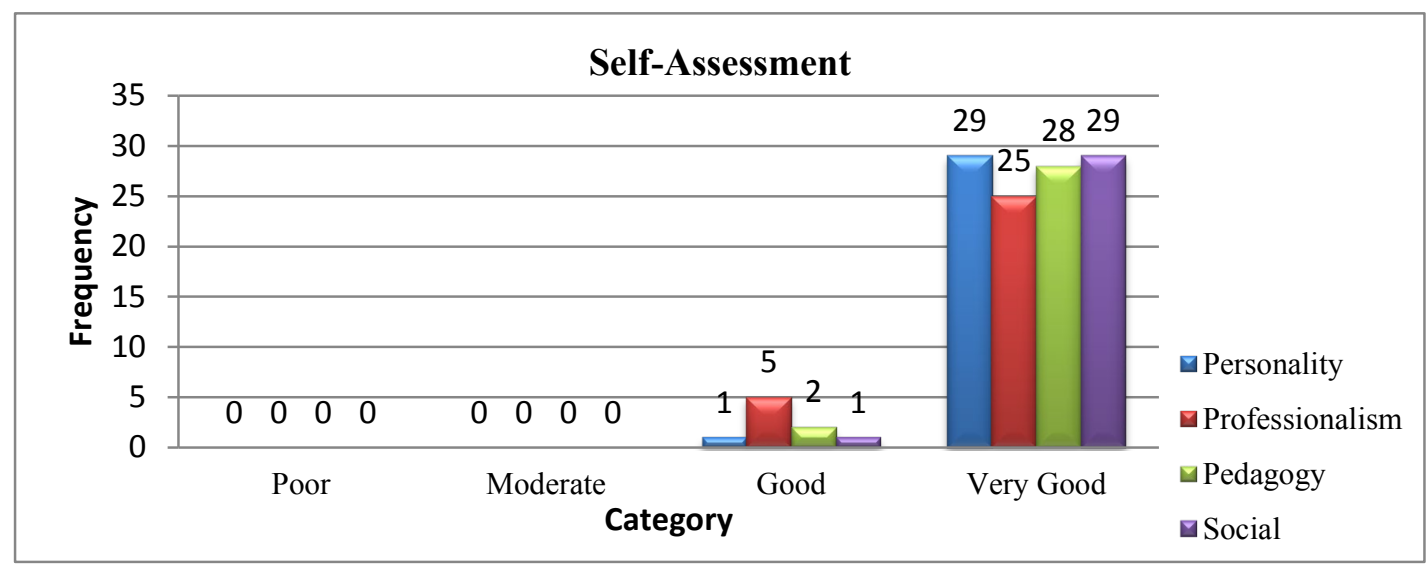

Figure 1. The Comparison on the Categorization for Each Competence within the Teacher Performance Based on the Self-Assessment

The results of the self-assessment toward the post-certification Natural History teacher performance for the Elementary School Degree throughout the Province of Yogyakarta Special Region show that each aspect of the teacher competence has fallen into the "Very Good" category. The statement is apparent from the "Very Good" category that has been found on most of the teachers in each aspect namely: (1) the personality competence $(96.70 \%)$; (2) the professionalism competence $(83.30 \%)$; (3) the pedagogy competence $(93.30 \%)$; and (4) the social competence $(96.70 \%)$. Next, a clear comparison on the categorization for each competence based on the school principal assessment might be consulted in Figure 2.

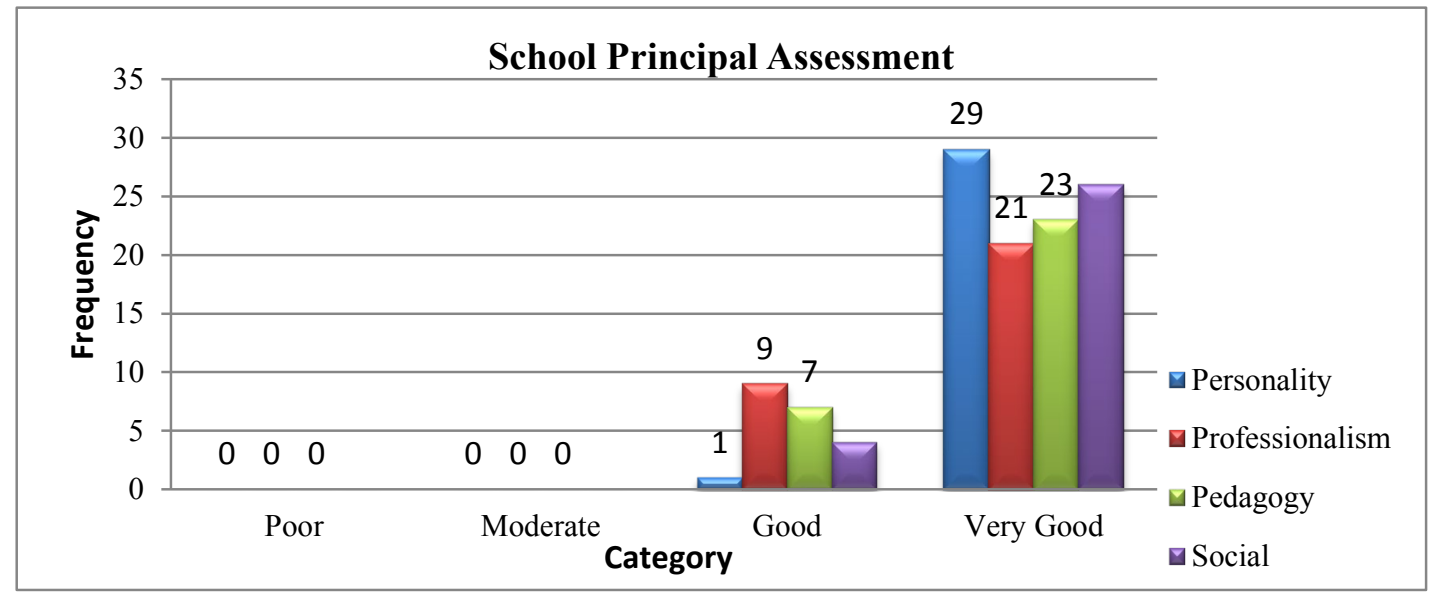

Figure 2. The Comparison on the Categorization for Each Competence within the Teacher Performance Based on the School Principal Assessment

The results of the school principal assessment (Figure 2) toward the post-certification Natural History teacher performance for the Elementary School Degree throughout the Province of Yogyakarta Special Region show that each aspect of the teacher competence has fallen into the "Very Good" category. The statement is apparent from the "Very Good" category that has been found on most of the teachers in each aspect namely: (1) the personality competence $(96.70 \%)$; (2) the professionalism competence $(76.70 \%)$; (3) the pedagogy competence $(70.00 \%)$; and (4) the social competence $(86.70 \%)$. Further-more, a clear comparison on the categorization for each competence based on the peer assessment might be consulted in Figure 3.

The results of the peer assessment toward the post-certification Natural History teacher performance for the Elementary School Degree throughout the Province of Yogyakarta Special Region show that each aspect of the teacher competence has fallen into the "Very Good" category. The statement is apparent from the "Very Good" category that has been found on most of the teachers in 
each aspect namely: (1) the personality competence $(96.70 \%)$; (2) the professionalism competence $(70.00 \%)$; (3) the pedagogy competence $(86.70 \%)$; and (4) the social competence $(83.30 \%)$. In addition, a clear comparison on the categorization for each competence based on the student assessment might be consulted in Figure 4.

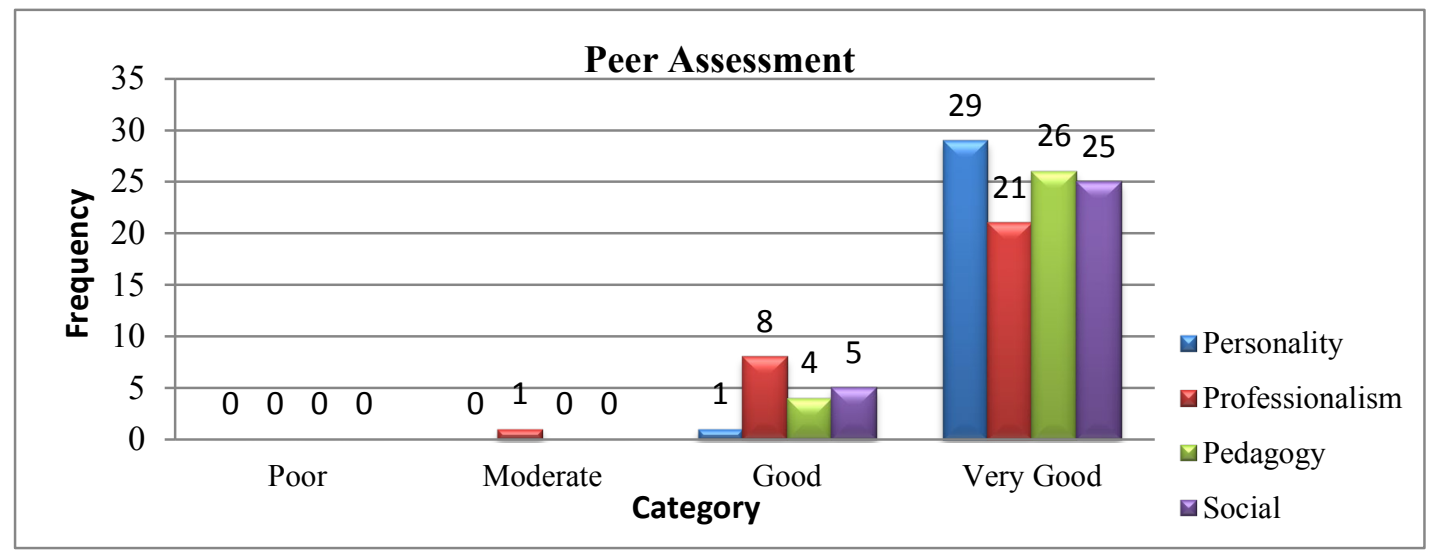

Figure 3. The Comparison on the Categorization for Each Competence within the Teacher Performance Based on the Peer Assessment

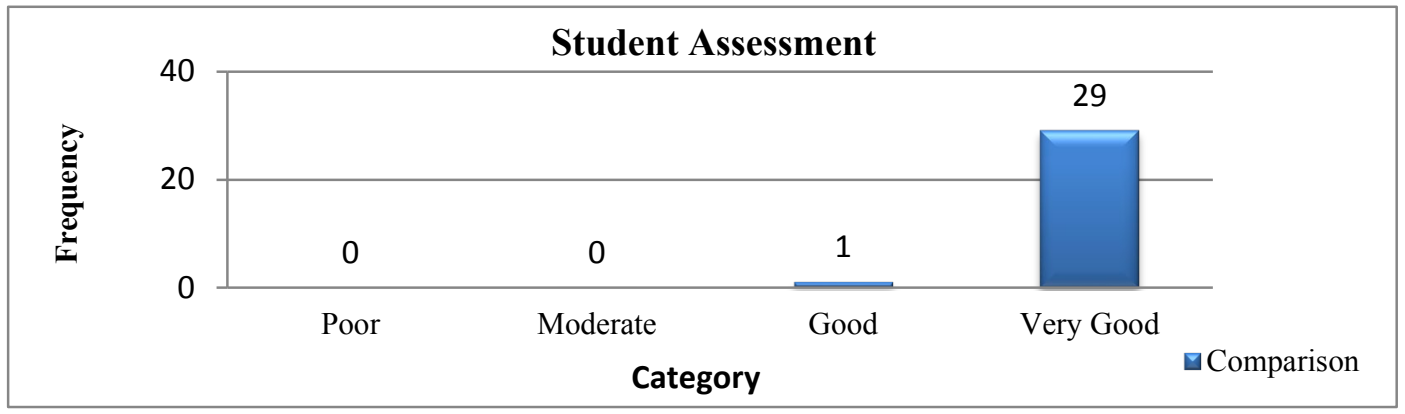

Figure 4. The Comparison on the Categorization for Each Competence within the Teacher Performance Based on the Student Assessment

The results of the student assessment toward the post-certification Natural History teacher performance for the Elementary School Degree throughout the Province of Yogyakarta Special Region show that each aspect of the teacher competence has fallen into the "Very Good" category $(96.70 \%)$. Last but not the least, a clear comparison on the categorization for each competence based on the observation might be consulted in Figure 5.

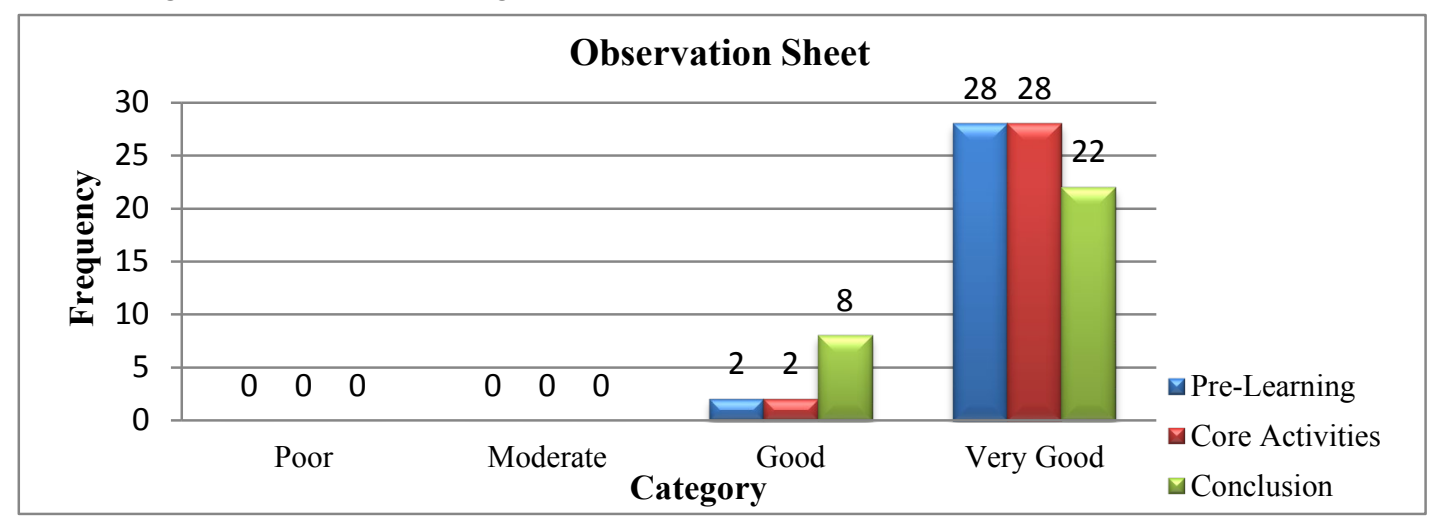

Figure 5. The Comparison on the Categorization for Each Competence within the Teacher Performance Based on the Observation

The objective of the study is to describe the post-certification Natural History teacher performance in the Province of Yogyakarta Special Region based on the self-assessment, the school principal assessment, the peer assessment and the student assessment. In addition, another objective of the 
study is to attain information on the teacher performance which includes the lesson plan, the learning implementation and the learning results assessment that the Natural History teachers for the Elementary School Degree have performed after they pass the certification program. As having been stated previously, the assessment toward the teacher performance consists of the self-assessment, the school principal assessment, the peer assessment and the student assessment. The self-assessment, the school principal assessment, and the peer assessment are conducted based on four competencies within the teacher performance namely the personality competence, the professionalism competence, the pedagogy assessment and the social assessment, while the student assessment are conducted toward the overall teacher performance.

According to Djohar $(2007$, p. 25$)$, the teacher performance covers three components of main duty namely the competence duty in the scientific domain that has been taught, the teaching profession duty and the skilfulness in implementing the competence and the profession. Specific to the case of Natural History, the Natural History teacher performance refers to the teacher performance in conducting his or her duty as having been reflected by the assessment results toward the personality competence, the professionalism competence, the pedagogy competence and the social competence and also be the lesson plan and the learning implementation within the Natural History learning process. Within the study, the assessment results toward the teachers' personality competence show that the teachers' personality competence throughout the Province of Yogyakarta Special Region has fallen into the "Very Good" category. In relation to these results, Mulyasa (2007) argues that in order to conduct the assigned duty well, professionally and responsibly a teacher should have well-established, stable and well-mannered personality. The personality of a teacher should have positive contribution toward the educational success especially in the teaching-learning process. The reason is that the personality of a teacher might impact the personality of his or her students. The good personality of a teacher is able to provide positive role toward the establishment of the students' personality in order to be a noble individual.

Then, the professionalism competence consists of the capacity to open the learning process, the teacher attitude toward the learning process, the learning materials mastery, the teaching-learning process or the learning process, the capacity to operate the learning media, the capacity to conclude the learning process and the capacity to perform follow up. In relation to this competence, the results of the three assessments within the study show that most of the Natural History teacher performance throughout the Province of Yogyakarta Special Region has fallen into the "Very Good" category. These results are supported by the respondents' characteristics, which show that $76.70 \%$ teachers who have been sampled in the study are Strata-1 Program graduates. In addition, there are $63.30 \%$ teachers who have attended the certified training / education programs for more than three times. Furthermore, the high figure of the students who used to design learning media also highly supports the teachers' professionalism. The professionalism of a teacher is highly important within the learning process. a professional teacher is able to provide the best learning process and eventually improve the educational quality in Indonesia.

Next, the pedagogy competence is related to the learning objective formulation, the learning materials selection, the learning strategy/method implementation, the appropriate learning media selection and the learning evaluation conduct. In relation to the pedagogy competence, the results of the study show that the Natural History teacher performance throughout the Province of Yogyakarta Special Region has fallen into the "Very Good" category. The sufficient capacity of the teachers in designing the Lesson Plan is expected to improve the learning process implementation within the classroom. Specifically, the sufficient capacity of the teachers in designing the Lesson Plan is expected to make the Natural History learning process be more effective.

Last but not the least, the social competence refers to the capacity of the teachers in establishing effective socialization and communication with the students, the fellow teachers, the teaching staffs, the parents or the foster parents and the surrounding communities. In relation to this competence, the results of the three assessments show that most of the Natural History teacher performance throughout the Province of Yogyakarta Special Region has fallen into the "Very Good" category. Such performance is supported by the high figure of the teachers who have been active in the social organizations $(90.00 \%)$ and in the educational organizations $(40.00 \%)$.

On the other hand, the results of the student assessment toward the teacher performance show that most of the teacher performance has fallen into the "Very Good" category $(96.70 \%)$ as well. Thus, 
these results imply that the presence of teacher certification programs has improved the teacher performance especially the Natural History teacher performance in the Province of Yogyakarta Special Region. In relation to the statement, the personality of a teacher before the students highly influence the success of the learning process since the personality competence deals with the capacity of a teacher in reflecting the well-established, stable, well-mannered, intelligent and dignified competence so that the students will look up to the teacher as their role model. Not to mention, in order to conduct his or her duty wel a teacher should have well-established, stable, and well-mannered personality (Hasriani, 2019; Mulyasa, 2007, p. 21). According to the Minister of National Education Regulation Number 16 of 2007c on the Academic Qualification Standards and the Teacher Competence, it is stated that the capacity within the context of personality competence standards consist of five main competencies namely: (1) taking actions in accordance to the nationally-governing religious, legal, social, and cultural norms in Indonesia; (2) displaying one's self as honest and noble personality in order to be the role model for the students and the surrounding communities; (3) displaying one's self as well-established, stable, well-mannered, intelligent and dignified personality; (4) displaying the work ethics, the high sense of responsibility, the sense of pride as a teacher, and the sense of confidence; and (5) abiding to the teachers' code of professional conduct. The five competencies serve as the basis in designing the instrument for uncovering the personality competence.

Teacher certification is a formal evidence that reflects the acknowledgment toward the teachers and the lecturers as having been formulated in the Law of Republic Indonesia Number 14 of 2005 on Teachers and Lecturers. The results of the teacher certification, which have been marked by the provision of teacher certificates for the teachers who have met the competence standards, make the teachers be more confident in being a sufficiently capable teacher within the conduct of their duty as the agent of learning and also within the manifestation of the national education objectives. In addition, the teacher certification program is also able to improve the process and the quality of the educational results and the teachers' dignity.

With regards to the teacher certification, the results of the study confirm that the presence of the teacher certification program is able to improve the quality and the professionalism of the teachers. Through the teacher certification process, it is expected that the competence and the professionalism of the teachers might be improved in accordance to the teacher competence standards that the government has desired since the professionalism competence is viewed from the capacity of mastering the learning materials in width and in depth. This competence is highly vital because it has direct relationship to the performance that has been displayed.

Teachers have very vital role for the activities within the teaching-learning process. The success within the teaching-learning activities in the school is not only determined by the curriculum, the management and the school facilities but also by significant influence that the teachers have. Therefore, through the presence of the certification it is expected that the teachers might have better professional competence so that the teaching-learning process will be achieved in maximum.

The results of the observation, in the same time, show that the Natural History teacher performance throughout the Province of Yogyakarta Special Region for the pre-learning activities has fallen into the "Very Good" category $(93.30 \%)$, for the core activities has fallen into the "Very Good" category $(93.30 \%)$ and for the conclusion has fallen into the "Very Good" category $(73.30 \%)$ as well. Altogether, these results confirm that the presence of the teacher certification is able to better the teacher performance, especially the Natural History teacher performance, throughout the Province of Yogyakarta Special Region.

\section{CONCLUSIONS}

Based on the results of the study and also the discussions within the study, several conclusions might be drawn. First of all, based on the four competencies, namely the personality competence, the professionalism competence, the pedagogy competence, and the social competence, the post-certification Natural History teacher performance for the Elementary School Degree from the self-assessment results, the school principal results and the peer assessment Results have fallen into the "Very Good" category. The details on these findings are as follows: (1) $96.70 \%$ for the personality competence; (2) $76.40 \%$ for the professionalism competence; (3) $83.30 \%$ for the pedagogy competence; and (4) $88.90 \%$ for the social competence. Then, from the results of the student assessment, it is found that the 
post-certification Natural History teacher performance throughout the Province of Yogyakarta Special Region has fallen into the "Very Good" category. Last but not the least, the results of the observation show that the Natural History teacher performance for the Elementary School Degree throughout the Province of Yogyakarta Special Region has fallen into the "Very Good" category for the pre-learning activities $(93.30 \%)$, for the core activities $(93.30 \%)$, and for the conclusion $(73.30 \%)$.

Departing from the conclusions, there are several suggestions that might be proposed. For the Natural History teachers, it is suggested that the teachers might improve the creativity and might provide new insights within the teaching-learning process so that the students will gain rich experience and knowledge and will also be a lifelong learner. Then, for the school principals, it is suggested that the teacher development/supervision, both in the academic domain and the professional domain, should be conducted continuously in order to improve the performance/professionalism of the teachers. Next, for the relevant parties, it is suggested that the relevant parties should take participation in enforcing the rights and the responsibilities of the teachers as having been mandated by the Law Number 14 of 2005 on Teachers and Lecturers. Last but not the least, for the future studies, it is suggested that the future researchers might pursue more development on the teacher performance evaluation by, for example, identifying the factors that influence the teacher performance.

\section{REFERENCES}

Alsrhid, A. M. M. (2012). Analytical study of the professional qualifications of the teacher in the Arab World. Journal of Education and Practice, 3(13), 17-38. https://www.iiste.org/Journals/index.php/JEP/article/view/3051

Arikunto, S. (2016). Dasar-dasar evaluasi pendidikan (5th ed.). Bumi Aksara.

Damanik, I. H. (2012). Penyiapan pendidik dan tenaga kependidikan yang berkarakter untuk membentuk generasi emas. Universitas Negeri Yogyakarta.

Departemen Pendidikan Nasional. (2007a). Peraturan Menteri Pendidikan Nasional (Mendiknas) RI Nomor 18 Tahun 2007 tentang sertifikasi guru dalam jabatan.

Departemen Pendidikan Nasional. (2007c). Peraturan Menteri Pendidikan Nasional RI No 16 Tahun 2007 tentang standar kualifikasi akademik dan kompetensi guru.

Departemen Pendidikan Nasional. (2010). sertifikasi guru dalam jabatan tahun 2010. Jakarta: kemeneterian Pendidikan Nasional Republik Indonesia.

Djohar, D. (2007). Pendidikan dan pembinaannya penerapannya dalam pendidikan dan undang undang guru. Sinar Grafika.

Fattah, N. (1999). Landasan manajemen pendidikan. PT Remaja Rosdakarya.

Gronlund, N. E. (1985). Measurement and evaluation in teaching. Macmillan College.

Grounlund, N., Linn, R., \& Gronlund, E. N. (1990). Measurement and evaluation in teaching.

Hasriani, G. (2019). Interview as a learning technique in speaking subject: Students' perspective. Language Circle: Journal of Language and Literature, 13(2). https://doi.org/10.15294/lc.v13i2.18976

Hastuti, S. (2005). Kontribusi hasil pelatihan guru dan supervisi kepala sekolah terhadap profesionalisme guru (Penelitian pada guru madrasah aliyah di Kota Semarang). Universitas Negeri Semarang.

Jalinus, N., \& Nabawi, R. A. (2017). Implementation of the PjBL model to enhance problem solving skill and skill competency of community college student. Jurnal Pendidikan Vokasi, 7(3), 304311. https://doi.org/10.21831/jpv.v7i3.14286

Mardapi, D., \& Herawan, T. (2019). Community-based teacher training: Transformation of sustainable teacher empowerment strategy in Indonesia. Journal of Teacher Education for Sustainability, 21(1), 48-66. https://doi.org/10.2478/jtes-2019-0004

Mulyasa, E. (2007). Standar kompetensi dan sertifikasi guru (M. Mukhlis (ed.)). Remaja Rosdakarya. Munir, A. (2008). Menjadi kepala sekolah efektif. Ar-Ruzz Media.

Nabila, H. (2016). The influence of pedagogic competence and professional competence to performance of teachers social studies in Trowulan district. International Conference on Ethics 
of Business, Economics, and Social Scienceyang Diselenggarakan Oleh Fakultas Ekonomi UNY, Tanggal, 16-17.

Natuna, D. A., \& Rinaldi, R. (2017). The competency of teacher entrepreneurship in teaching. International Journal of Economic, Business and Applications, 2(1), 41-52. https://ijeba.ejournal.unri.ac.id/index.php/IJEBA/article/view/4648

Nisa, A. F. (2015). Implementasi multiple intelligences dalam pendidikan dasar. Al-Bidayah: Jurnal Pendidikan Dasar Islam, 7(2). https://doi.org/10.14421/al-bidayah.v7i2.81

Payong, M. R. (2011). Sertifikasi profesi guru: konsep dasar, problematika, dan implementasinya. Indeks.

Sariwulan, T., Agung, I., Sudrajat, U., \& Atmadiredja, G. (2019). The influence of job expectation, job satisfaction, and government policy towards the work stress, job enthusiasm and continuance commitment of the honorarium teacher. Jurnal Cakrawala Pendidikan, 38(2), 305-319. https://doi.org/10.21831/cp.v38i2.24380

Sasmoko, Doringin, F., Indrianti, Y., Goni, A. M., \& Ruliana, P. (2018). Indonesian teacher engagement index (ITEI): An emerging concept of teacher engagement in Indonesia. IOP Conference Series: Materials Science and Engineering, 306, 12119. https://doi.org/10.1088/1757-899x/306/1/012119

Sudijono, A. (2012). Pengantar evaluasi pendidikan. PT Raja Grafindo Persada.

Suparlan, S. (2008). Menjadi guru efektif. Hikayat Publishing.

Suyanto, S., \& Abbas, A. (2001). Wajah dan dinamika pendidikan anak bangsa. Adicita Karya Nusa.

Weiss, C. H. (1997). Theory-based evaluation: Past, present, and future. New Directions for Evaluation, 1997(76), 41-55. https://doi.org/10.1002/ev.1086

Widiastini, N. P. D., Candiasa, I. M., \& Suharta, I. (2018). Development of interactive multimedia learning surface area of solid geometry. International Journal of Physics \& Mathematics, 1(1), 1-7. https://doi.org/10.31295/ijpm.v1n1.38 